\title{
ASSESSMENT OF GROUNDWATER QUALITY FOR DRINKING PURPOSE IN RAI BLOCK, SONIPAT DISTRICT, HARYANA, INDIA
}

\author{
Anup Kumar ${ }^{1 *}$, Shubham Sharma ${ }^{2}$ and V.S. Arya ${ }^{3}$ \\ ${ }^{1}$ Front Office-HARSAC, Panchkula, Haryana, India \\ ${ }^{2}$ Deptt.of Geology, Kurukshetra University, Kurukshetra, Haryana, India \\ ${ }^{3}$ Haryana Space Applications Centre (HARSAC), Hisar, Haryana, India
}

\begin{abstract}
Water is important for survival of living beings on the planet Earth. Drinking water quality should be as per drinking water standards to avoid the health effects. Anthropogenic activities have deteriorated the groundwater quality. In urban areas groundwater quality is more or less not suitable for drinking purpose. Shallow water table areas are more prone to water pollution due to anthropogenic activities. Rai block is located in Sonipat district of Haryana. The block covers an area of 280.49 sq.km. In the present study 20 groundwater samples in Rai block were collected in the month of January, 2019. The samples were analyzed using Field Water Testing Kit prepared by Tamil Nadu water Supply and Drainage Board, Chennai for twelve chemical parameters-pH, alkalinity, hardness, chloride, total dissolved solids (TDS), fluoride, iron, nitrate, nitrite, ammonia, phosphate and residual chlorine. Chemical analysis of groundwater samples show that pH 6.5 to 9, alkalinity 100-2700 mg/l, hardness 130 $920 \mathrm{mg} / \mathrm{l}$, chloride 20 - $750 \mathrm{mg} / \mathrm{l}$, TDS $828-3350 \mathrm{mg} / \mathrm{l}$, fluoride $1-3 \mathrm{mg} / \mathrm{l}$, iron nil to 5 $\mathrm{mg} / \mathrm{l}$, ammonia 0.5 - $1 \mathrm{mg} / \mathrm{l}$, nitrite $0.2-1.0 \mathrm{mg} / \mathrm{l}$, nitrate $45-100 \mathrm{mg} / \mathrm{l}$, phosphate nil to 2 $\mathrm{mg} / \mathrm{l}$ and residual chlorine nil to $0.2 \mathrm{mg} / \mathrm{l}$. Groundwater is non-potable at Rasoi-2 (pH 9, alkalinity $860 \mathrm{mg} / \mathrm{l}$, fluoride $2 \mathrm{mg} / \mathrm{l}$, iron $5 \mathrm{mg} / \mathrm{l}$, ammonia $1 \mathrm{mg} / \mathrm{l}$, nitrate 100mg/l), Rasoi-1 (alkalinity $2700 \mathrm{mg} / \mathrm{l}$, TDS $3350 \mathrm{mg} / \mathrm{l}$, fluoride $3 \mathrm{mg} / \mathrm{l}$, nitrate $100 \mathrm{mg} / \mathrm{l}$ ), Jakholi-3 (alkalinity $780 \mathrm{mg} / \mathrm{l}$, nitrate $100 \mathrm{mg} / \mathrm{l}$ ), Nathupur (alkalinity $850 \mathrm{mg} / \mathrm{l}$, fluoride $3 \mathrm{mg} / \mathrm{l}$, ammonia $1 \mathrm{mg} / \mathrm{l}$ ), Bahalgarh (Hardness $920 \mathrm{mg} / \mathrm{l}$, TDS $2388 \mathrm{mg} / \mathrm{l}$, fluoride $2 \mathrm{mg} / \mathrm{l}$, ammonia 1mg/l), Jatheri-1 (Hardness $700 \mathrm{mg} / \mathrm{l}$ ), Liwaspur (Hardness $800 \mathrm{mg} / \mathrm{l}$, TDS $2064 \mathrm{mg} / \mathrm{l}$, ammonia $1 \mathrm{mg} / \mathrm{l}$ ), Sabauli (fluoride $3 \mathrm{mg} / \mathrm{l}$, nitrate 100 mg/l), Nangal Kalan (fluoride 3 mg/l, ammonia 1 mg/l, nitrate 75 mg/l), Patla-2 (iron 3mg/l, ammonia 1 mg/l), Jakholi-2 (iron 1 mg/l, nitrate 100 mg/l, phosphate 2 mg/l ), Sewli-1(ammonia 1mg/l), Rai-1( ammonia $1 \mathrm{mg} / \mathrm{l}$ ), Jat Joshi (ammonia $1 \mathrm{mg} / \mathrm{l}$ ), Jat Joshi-2 (ammonia $1 \mathrm{mg} / \mathrm{l}$ ). The study is highly useful for monitoring groundwater quality for drinking purpose in the study area.
\end{abstract}

\section{Keywords}

Groundwater, quality, drinking, Rai, Sonipat, Haryana.

\section{INTRODUCTION}

Water is important for survival of human beings and other living beings on the planet earth. In the present developmental activities water is polluted and not fit for drinking purposes. In industrial and high population density areas groundwater is polluted and not suitable for drinking purpose as per BIS drinking water standards. The need of the hour is to protect this precious natural resource for future generations. On various aspects of groundwater quality many workers have done good work Agrawal (2009), Ana et al. (2018), Balakrishnan, et al (2011), Das and Nag (2015), Durgadevagi, et al. (2016), Hussain and Prasad (2013). Jeihouni, et al. (2014), Mahadevaswamy, et al. (2011), Okoye, et al. (2016), Pandian and Jeyachandran (2014), 
Patel and Dhiman (2011), Rajesh, (2016), Sarkar, et al. (2012), Satyanarayana, et al. (2013), Saxena and Saxena (2015), Sengupta and Dalwani (2008), Shahida and Ummatul (2015), Sheikh and Kumari (2017), Sinha, et al. (2018), Subramani, et al. (2012), Thomas et al. (2015), Topper and Horn (2011), Vashisth (2017).

\section{STUDY AREA}

Rai block is located in Sonipat district of Haryana. The block covers 280.49 sq.km area. Geologically the block has soils of quarternary age. Rai is an industrial area with many types of industries working in the area. It is located on national highway adjacent to Delhi.

\section{OBJECTIVE}

The main objective was to assess groundwater quality for drinking purpose in the study area.

\section{MATERIALS AND METHODS}

Twenty groundwater samples were collected in plastic bottles from different parts of the Rai block in the month of January, 2019. Groundwater samples were analyzed using Field Water Testing Kit prepared by Tamil Nadu Water Supply and Drainage Board, Chennai for twelve chemical parameters$\mathrm{pH}$, alkalinity, hardness, chloride, total dissolved solids, fluoride, iron, ammonia, nitrate, nitrite, phosphate, residual chlorine. Chemical data entered in excel software and prepared the bar graphs of each parameter for all the sample location. Results were compared with BIS drinking water standards to know the pot-ability and non-potability of groundwater for drinking purpose.

\section{RESULTS AND DISCUSSION}

Results of twenty groundwater samples are given in Table 1 and BIS drinking water standards are given in Table 2. Parameter wise groundwater quality is given below:

Table 1: Results of chemical analysis of groundwater samples (in mg/l except pH).

\begin{tabular}{|c|c|c|c|c|c|c|c|c|c|c|c|c|c|c|}
\hline $\begin{array}{l}\text { Sample } \\
\text { Location }\end{array}$ & Latitude & Longitude & $\mathrm{pH}$ & $\begin{array}{l}\text { Alka } \\
\text { linity }\end{array}$ & Hardness & $\begin{array}{l}\text { Chlo } \\
\text { ride }\end{array}$ & TDS & $\begin{array}{l}\text { Fluo } \\
\text { ride }\end{array}$ & Iron & $\begin{array}{c}\text { Amm } \\
\text { onia }\end{array}$ & $\begin{array}{l}\text { Nit } \\
\text { rite }\end{array}$ & $\begin{array}{l}\text { Nit } \\
\text { rate }\end{array}$ & $\begin{array}{l}\text { Phos } \\
\text { phate }\end{array}$ & $\begin{array}{l}\text { Residual } \\
\text { Chlorine }\end{array}$ \\
\hline Rasoi-2 & $2854^{\prime} 25^{\prime \prime}$ & $7766^{\prime} 45^{\prime \prime}$ & 9 & 860 & 570 & 20 & 1380 & 2 & 5 & 1 & 1 & 100 & 0 & 0.2 \\
\hline Rasoi-1 & 2854 '6" & 77 6'44" & 7 & 2700 & 300 & 350 & 3350 & 3 & 0 & 0.5 & 1 & 100 & 0 & 0 \\
\hline Bahalgarh & $2857^{\prime} 29 "$ & 77 5'36" & 7.5 & 400 & 920 & 670 & 2388 & 2 & 0 & 1 & 0.5 & 45 & 0 & 0 \\
\hline Sewli-1 & $2855^{\prime} 47^{\prime \prime}$ & 77 7'37" & 7.5 & 600 & 600 & 50 & 1500 & 1 & 0 & 1 & 0.5 & 45 & 0 & 0 \\
\hline Rai-1 & $2856 ' 27^{\prime \prime}$ & $775^{\prime} 53^{\prime \prime}$ & 7.5 & 350 & 430 & 550 & 1596 & 1.5 & 0 & 1 & 0.5 & 45 & 0 & 0 \\
\hline Jakholi-1 & $2855^{\prime} 45^{\prime \prime}$ & 77 8'58" & 7 & 450 & 600 & 250 & 1560 & 1.5 & 0 & 0.5 & 0.5 & 45 & 0 & 0 \\
\hline Jatheri-1 & $2855^{\prime} 19^{\prime \prime}$ & 77 4'24" & 7 & 600 & 700 & 350 & 1980 & 1.5 & 0 & 0.5 & 0.5 & 45 & 0 & 0.2 \\
\hline Sewli-2 & $2855^{\prime} 20^{\prime \prime}$ & 77 7'33" & 7.5 & 400 & 250 & 110 & 912 & 1 & 0 & 0.5 & 0.5 & 45 & 0 & 0 \\
\hline Jakholi-3 & $2855^{\prime} 58^{\prime \prime}$ & 77 8'29" & 7.5 & 780 & 300 & 100 & 1416 & 1 & 0 & 0.5 & 1 & 100 & 0 & 0.2 \\
\hline Sewli-3 & $2855^{\prime} 47^{\prime \prime}$ & 77 7'35" & 7.5 & 380 & 250 & 60 & 828 & 1 & 0 & 0.5 & 0.5 & 45 & 0 & 0 \\
\hline Pritampura & $2854^{\prime} 7^{\prime \prime}$ & 77 5'54" & 6.5 & 420 & 130 & 530 & 1296 & 1.5 & 0 & 0.5 & 0.5 & 45 & 0 & 0.2 \\
\hline Patla-2 & $2855^{\prime} 21^{\prime \prime}$ & 77 8'26" & 7.5 & 500 & 290 & 250 & 1248 & 1 & 3 & 1 & 0.5 & 45 & 0 & 0 \\
\hline Nathupur & 2854 '6" & 77 6'20" & 7.5 & 850 & 370 & 190 & 1692 & 3 & 0 & 1 & 1 & 100 & 0 & 0 \\
\hline Jat Joshi & $2858^{\prime} 7^{\prime \prime}$ & $774^{\prime} 7^{\prime \prime}$ & 7.5 & 370 & 360 & 280 & 1212 & 1.5 & 0 & 1 & 0.5 & 45 & 1 & 0 \\
\hline Jat Joshi-2 & $2858^{\prime} 7^{\prime \prime}$ & 77 4'29" & 7.5 & 430 & 380 & 350 & 1392 & 1.5 & 0 & 1 & 0.5 & 45 & 0.5 & 0 \\
\hline Jakholi-2 & $2855^{\prime} 30^{\prime \prime}$ & 778 8'55" & 6.5 & 100 & 240 & 750 & 1308 & 1.5 & 1 & 0.5 & 1 & 100 & 2 & 0.2 \\
\hline Sabauli & $2853^{\prime} 23^{\prime \prime}$ & 77 5'42" & 7.5 & 270 & 250 & 350 & 1044 & 3 & 0 & 0.5 & 1 & 100 & 0 & 0 \\
\hline Liwaspur & $2857^{\prime} 53^{\prime \prime}$ & 77 5'11" & 8.5 & 520 & 800 & 400 & 2064 & 1.5 & 0.3 & 1 & 0.5 & 45 & 0 & 0 \\
\hline Patla & $2854^{\prime} 53^{\prime \prime}$ & 77 8'19" & 7 & 340 & 500 & 180 & 1224 & 1 & 0 & 0.5 & 0.2 & 45 & 0 & 0 \\
\hline $\begin{array}{l}\text { Nangal } \\
\text { Kalan-1 }\end{array}$ & $2854^{\prime} 23^{\prime \prime}$ & 77 7'24" & 7.5 & 240 & 450 & 80 & 924 & 3 & 0 & 1 & 1 & 75 & 1 & 0 \\
\hline
\end{tabular}


Table 2: Drinking water standards (IS 10500:2012).

\begin{tabular}{|c|c|c|c|c|}
\hline \multirow[t]{2}{*}{ S. No. } & \multirow[t]{2}{*}{ Parameter } & \multicolumn{2}{|c|}{ Potable } & \multirow[t]{2}{*}{ Non-Potable } \\
\hline & & Desirable & Permissible & \\
\hline 1. & $\mathrm{pH}$ & 6.5 to 8.5 & -- & $<6.5$ to $>8.5$ \\
\hline 2. & Total Hardness (mg/l) & $<200$ & $200-600$ & $>600$ \\
\hline 3. & Iron (mg/l) & $<0.3$ & -- & $>0.3$ \\
\hline 4. & Chloride (mg/l) & $<250$ & $250-1000$ & $>1000$ \\
\hline 5. & Total Dissolved Solids (mg/l) & $<500$ & $500-2000$ & $>2000$ \\
\hline 6. & Nitrate (mg/l) & $<45$ & -- & $>45$ \\
\hline 7. & Nitrite (mg/l) & $<1.0$ & - & $>1.0$ \\
\hline 8. & Fluoride (mg/l) & $<1.0$ & $1.0-1.5$ & $>1.5$ \\
\hline 9. & Phosphate (mg/l) & $<1.0$ & - & $>1.0$ \\
\hline 10. & Residual Chlorine (mg/l) & $<0.2$ & $0.2-1$ & $>1.0$ \\
\hline 11. & Ammonia (mg/l) & $<0.5$ & -- & $>0.5$ \\
\hline 12. & Alkalinity (mg/l) & $<200$ & $200-600$ & $>600$ \\
\hline
\end{tabular}

\section{i. $\mathbf{p H}$}

$\mathrm{pH}$ is a measure of acidity or basicity of water. Water is potable between the range 6.5 to 8.5 and non-potable below 6.5 and above 8.5. pH ranges 6.5 to 9 in the study area. In the study area $\mathrm{pH}$ is desirable at nineteen sample locations and non-potable at Rasoi-2 sample location (pH 9). (Table 1, Table 2, Figure 1).

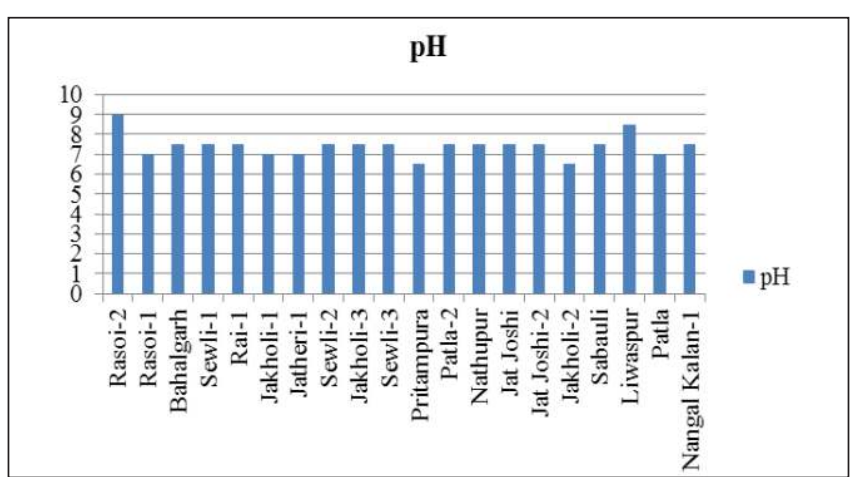

Figure 1: pH in groundwater samples

\section{ii. Alkalinity}

Alkalinity is a measure of water's ability to neutralize acids. In the study area alkalinity varies from $100 \mathrm{mg} / \mathrm{l}$ to $2700 \mathrm{mg} / \mathrm{l}$. At one sample location (Jakholi) alkalinity $100 \mathrm{mg} / \mathrm{l}$ is desirable $(<200 \mathrm{mg} / \mathrm{l})$, at fifteen sample locations alkalinity is permissible (200-600 mg/l) and at four sample locations alkalinity is nonpotable (>600 mg/l) (Table 1, Table 2, Figure 2).

\section{iii. Hardness}

Hard water has high concentration of calcium and magnesium carbonates. In the study area hardness varies from $130 \mathrm{mg} / \mathrm{l}$ to $920 \mathrm{mg} / \mathrm{l}$. Hardness is desirable at one sample location (Pritampura $130 \mathrm{mg} / \mathrm{l}$ ), permissible at sixteen sample locations and non-potable at three sample locations (Table 1, Table 2, Figure 3).

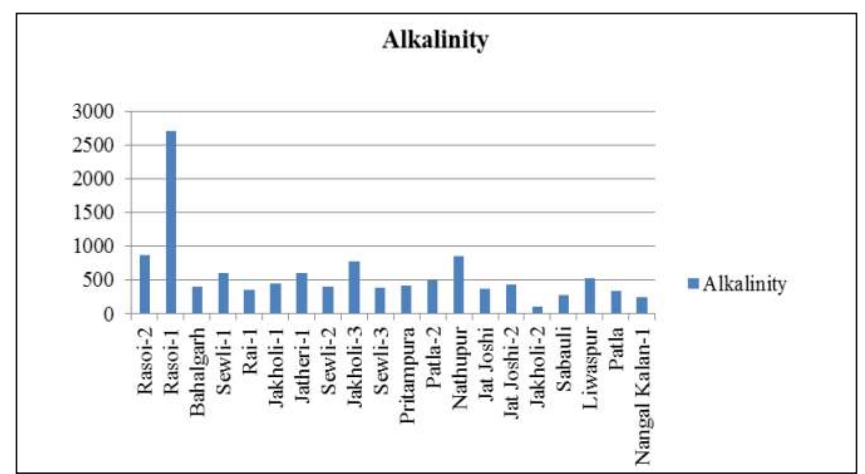

Figure 2:Alkalinity (mg/l) in groundwater samples .

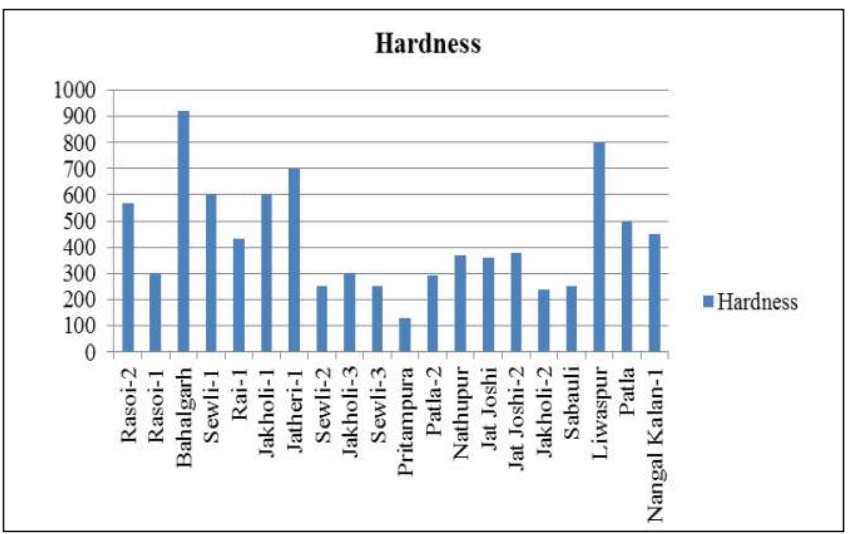

Figure 3:Hardness (mg/l) in groundwater samples.

\section{iv. Chloride}

Chloride is available in nature as salts of sodium $(\mathrm{NaCl})$, potassium $(\mathrm{KCl})$, and calcium $(\mathrm{CaCl} 2)$.Chloride is an anion and formed when the element chlorine gains an electron or when a compound such as hydrogen chloride is dissolved in water or other polar solvents. In the study area, chloride varies from $20 \mathrm{mg} / \mathrm{l}$ to $750 \mathrm{mg} / \mathrm{l}$. At eight sample locations chloride is desirable $(<250 \mathrm{mg} / \mathrm{l})$ and at twelve locations 


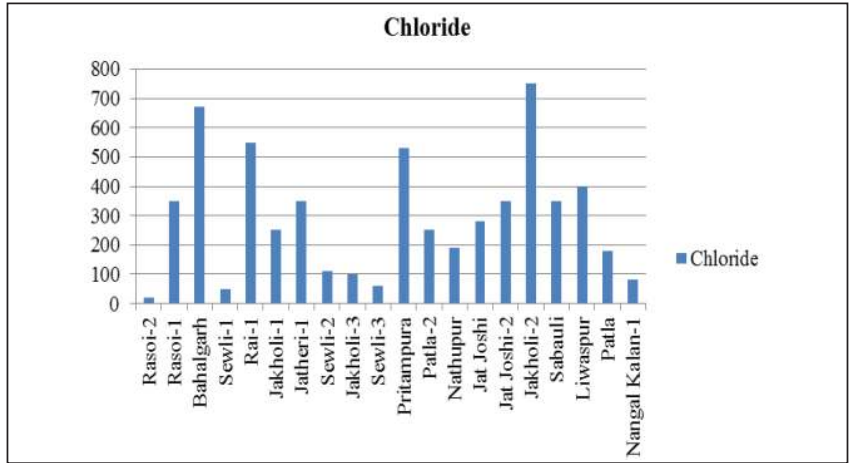

Figure 4: Chloride (mg/l) in groundwater samples.

chloride is permissible (250-1000 mg/l) (Table 1, Table 2, Figure 4).

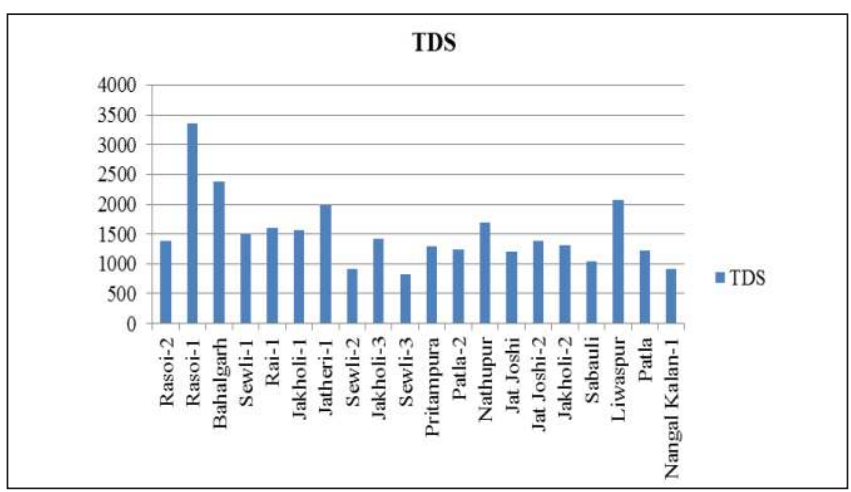

Figure 5: Total dissolved solids (TDS) (mg/l) in groundwater samples.

\section{v. Total Dissolved Solids (TDS)}

Total dissolved solids (TDS) represents the combined content of all inorganic and organic substance in water. In general, the TDS concentration is the sum of the cations and anions ions in the water. In the study area, TDS varies from $828 \mathrm{mg} / \mathrm{l}$ to 2388 $\mathrm{mg} / \mathrm{l}$. At seventeen sample locations TDS is permissible ( $500-2000 \mathrm{mg} / \mathrm{l})$ and three sample locations non-potable (>2000 mg/l) (Table 1, Table 2, Figure 5).

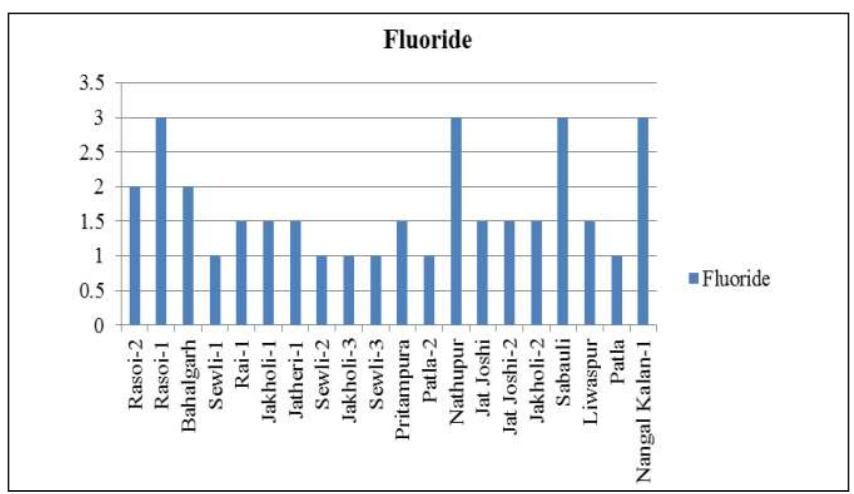

Figure 6: Fluoride (mg/l) in groundwater samples.

\section{vi. Fluoride}

Fluoride occurs naturally in soils and rocks. Fluoride more than 1.5 ppm in drinking water causes dental cavities, skeletal weakness and other bone diseases. In the study area, fluoride varies from $1 \mathrm{mg} / \mathrm{l}$ to $3 \mathrm{mg} / \mathrm{l}$. At six sample locations fluoride is desirable (<1 mg/l), eight sample locations permissible (1-
$1.5 \mathrm{mg} / \mathrm{l})$ and six sample locations non-potable (>1.5 mg/l) (Table 1, Table 2, Figure 6).

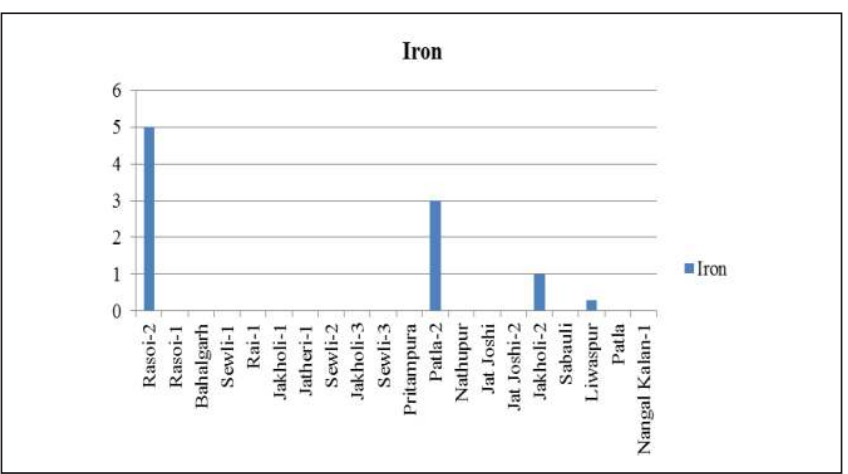

Figure 7: Iron (mg/l) in groundwater samples.

vii. Iron

Iron is commonly found in nature in its oxides form and occurs in soils,sediments and rocks. Iron is the second most abundant metal in the Earth's crust. In the study area iron varies between nil to $5 \mathrm{mg} / \mathrm{l}$. At seventeen sample locations iron is desirable $(<0.3 \mathrm{mg} / \mathrm{l})$ and three sample locations nonpotable (>0.3 mg/l) (Table 1, Table 2, Figure 7).

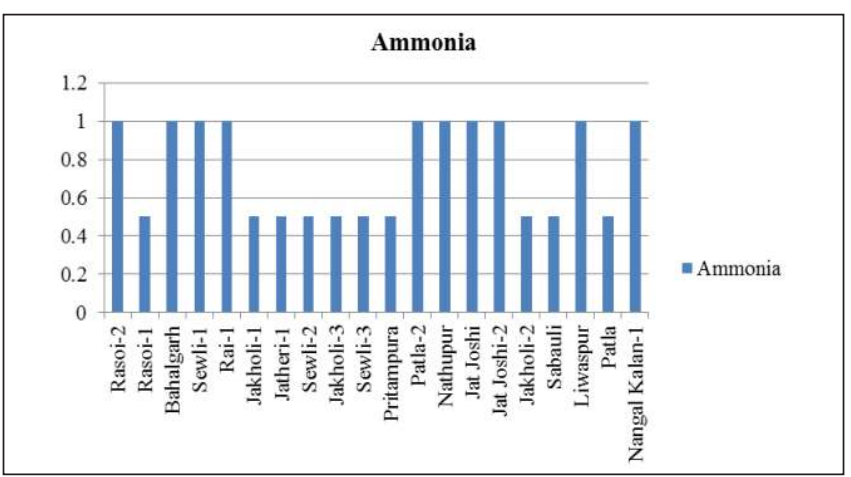

Figure 8: Ammonia (mg/l) in groundwater samples.

\section{viii. Ammonia}

Ammonia is a compound contains nitrogen and hydrogen. In the study area, ammonia varies from 0.5 to $1 \mathrm{mg} / \mathrm{l}$. At ten sample locations ammonia is desirable $(<0.5 \mathrm{mg} / \mathrm{l})$ and ten sample locations non-potable (>0.5 mg/l) (Table 1, Table 2, Figure 8).

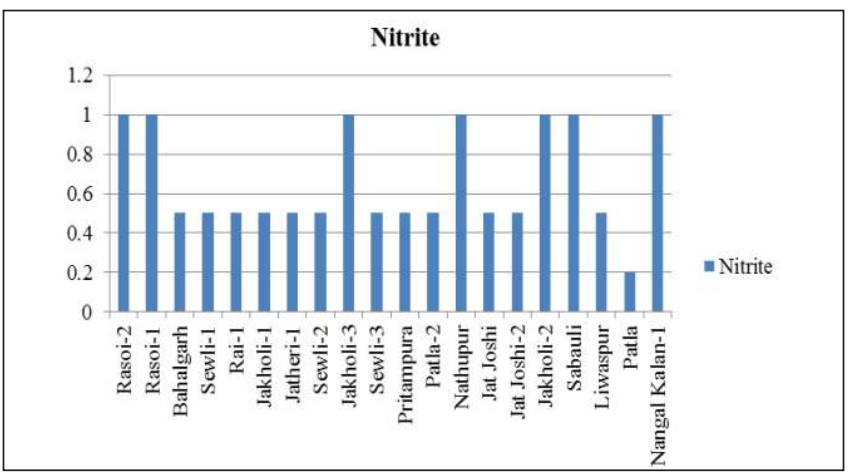

Figure 9: Nitrite (mg/l) in groundwater samples.

\section{ix. Nitrite}

Nitrite is ion having chemical formula NO2. In the study area, 
nitrite varies from $0.2 \mathrm{mg} / \mathrm{l}$ to $1 \mathrm{mg} / \mathrm{l}$. At all the twenty sample locations nitrite is desirable ( $<1 \mathrm{mg} / \mathrm{l}$ ) (Table 1, Table 2, Figure 9).

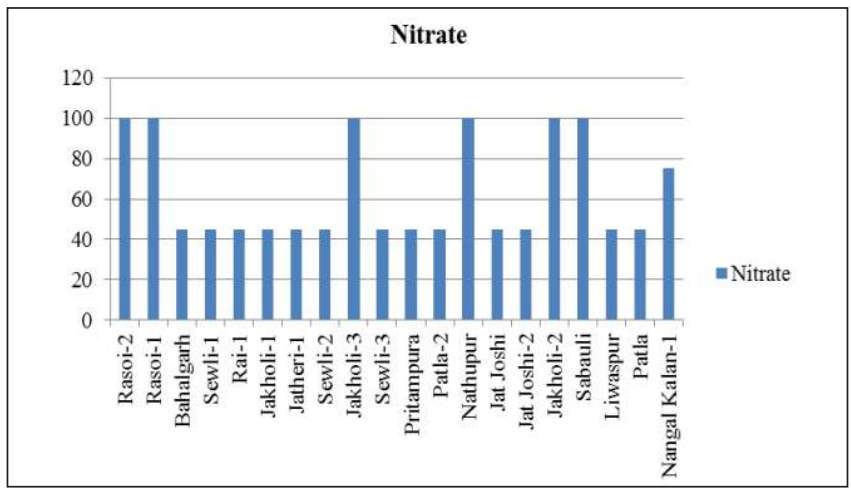

Figure 10: Nitrate $(\mathrm{mg} / \mathrm{l})$ in groundwater samples.

\section{$x$. Nitrate}

Nitrate (NO3) is inorganic compound. High nitrate level in drinking water can cause blue baby disease (Methemoglobinema) especially in infants less than six months old. In the study area nitrate varies from $45 \mathrm{mg} / \mathrm{l}$ to $100 \mathrm{mg} / \mathrm{l}$. At thirteen sample locations nitrate is desirbale ( $<45 \mathrm{mg} / \mathrm{l})$ and seven locations non-potable ( $>45 \mathrm{mg} / \mathrm{l})$ (Table 1, Table 2, Figure 10).

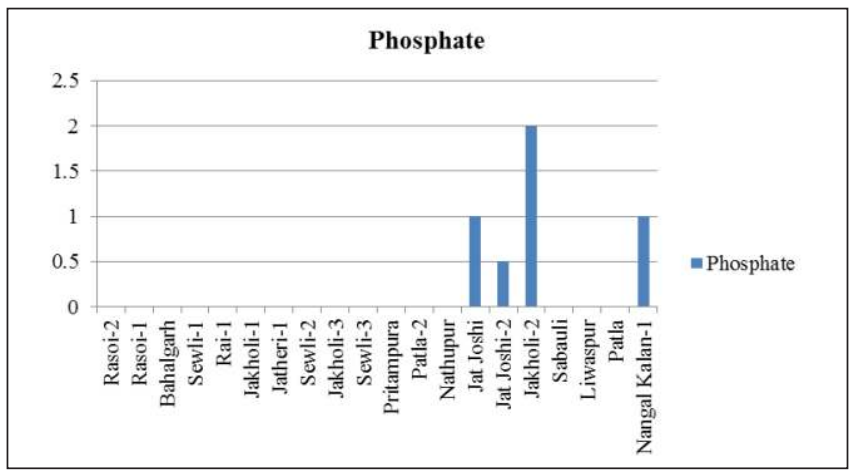

Figure 11: Phosphate (mg/l) in groundwater samples.

\section{xi. Phosphate}

Phosphate is a compound containing phosphorus. In the study area, phosphate varies from nil to $2 \mathrm{mg} / \mathrm{l}$. At nineteen sample locations phosphate is desirable $(<1 \mathrm{mg} / \mathrm{l})$ and one sample location non-potable (>1 mg/l) (Table 1, Table 2, Figure 11).

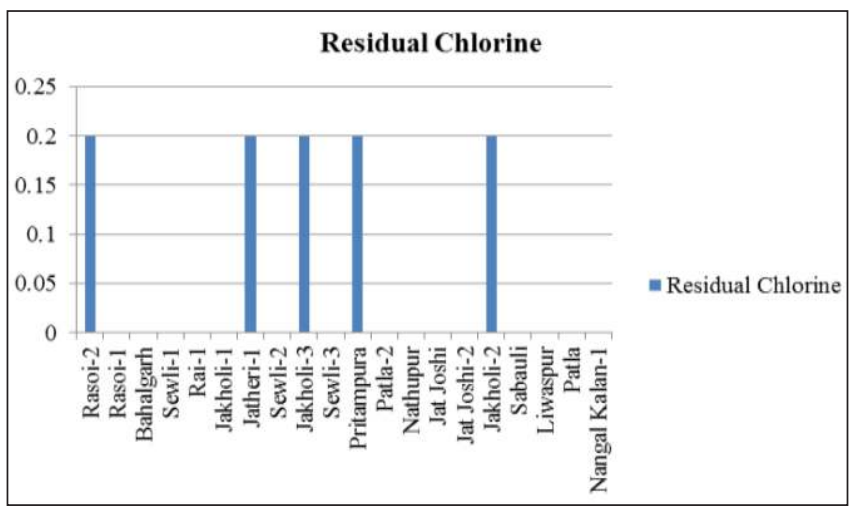

Figure 12: Residual chlorine (mg/l) in groundwater samples.

\section{xii. Residual Chlorine}

Presence of residual chlorine in drinking water indicates that a sufficient amount of chlorine is added to the water to deactivate the bacteria and viruses that cause diarrhea. In the study area, residual chlorine varies from nil to $0.2 \mathrm{mg} / \mathrm{l}$. At all the twenty sample locations residual chlorine is desirable $(<$ $0.2 \mathrm{mg} / \mathrm{l}$ ) (Table 1, Table 2, Figure 12).

\section{CONCLUSION}

Groundwater is non-potable at fifteen sample locations viz. Rasoi-2 (pH 9, alkalinity $860 \mathrm{mg} / \mathrm{l}$, fluoride $2 \mathrm{mg} / \mathrm{l}$, iron 5 mg/l, ammonia $1 \mathrm{mg} / \mathrm{l}$, nitrate 100mg/l), Rasoi-1 (alkalinity $2700 \mathrm{mg} / \mathrm{l}$, TDS $3350 \mathrm{mg} / \mathrm{l}$, fluoride $3 \mathrm{mg} / \mathrm{l}$, nitrate $100 \mathrm{mg} / \mathrm{l}$ ), Jakholi-3 (alkalinity $780 \mathrm{mg} / \mathrm{l}$, nitrate $100 \mathrm{mg} / \mathrm{l}$ ), Nathupur (alkalinity $850 \mathrm{mg} / \mathrm{l}$, fluoride $3 \mathrm{mg} / \mathrm{l}$, ammonia $1 \mathrm{mg} / \mathrm{l}$ ), Bahalgarh (Hardness 920 mg/l, TDS 2388 mg/l, fluoride 2 $\mathrm{mg} / \mathrm{l}$, ammonia 1mg/l), Jatheri-1 (Hardness $700 \mathrm{mg} / \mathrm{l}$ ), Liwaspur (Hardness 800 mg/l, TDS 2064 mg/l, ammonia 1 $\mathrm{mg} / \mathrm{l}$ ), Sabauli (fluoride $3 \mathrm{mg} / \mathrm{l}$, nitrate $100 \mathrm{mg} / \mathrm{l}$ ), Nangal Kalan (fluoride $3 \mathrm{mg} / \mathrm{l}$, ammonia $1 \mathrm{mg} / \mathrm{l}$, nitrate $75 \mathrm{mg} / \mathrm{l}$ ), Patla-2 (iron 3mg/l, ammonia 1 mg/l), Jakholi-2 (iron 1 mg/l, nitrate $100 \mathrm{mg} / \mathrm{l}$, phosphate $2 \mathrm{mg} / \mathrm{l}$ ), Sewli-1 (ammonia 1mg/l), Rai-1( ammonia $1 \mathrm{mg} / \mathrm{l}$ ), Jat Joshi (ammonia $1 \mathrm{mg} / \mathrm{l}$ ), Jat Joshi-2 (ammonia $1 \mathrm{mg} / \mathrm{l}$ ). Groundwater is potable at Patla, Pitampur,Sewli-2, Sewli-3 and Jakholi-1 sample locations. The study is highly useful for monitoring groundwater quality for drinking purpose in the study area.

\section{REFERENCES}

Agrawal, Ranjana (2009). Study of physico-chemical parameters of groundwater quality of Dudu town in Rajasthan, Rasayan Journal Chem., 2 (4): 969-971.

Ana Elizabeth Marín Celestino, Diego Armando Martínez Cruz, Elena Maria Otazo Sanchez, Francisco Gavi Reyes and David Vasquez Soto ID (2018). Groundwater quality assessment: an improved approach to K-means clustering, principal component analysis and spatial analysis: a case study, Water, 10 (437):1-21.

Balakrishnan, P., Saleem, Abdul and Mallikarjun, N. D. (2011). Groundwater quality mapping using geographic information system (GIS): A case study of Gulbarga City, Karnataka, India, African Journal of Environmental Science and Technology, 5 (12): 1069-1084.

Das, Shreya and Nag, S. K. (2015). Deciphering groundwater quality for irrigation and domestic purposes-a case study in Suri I and II blocks, Birbhum District, West Bengal, India, Journal Earth System Sciences, 124 (5): 965992.

Durgadevagi, S., Annadurai, R. and Meenu, Mohan (2016). Spatial and temporal mapping of groundwater quality using GIS based water quality index (a case study of SIPCOTPerundurai, Erode, Tamil Nadu, India), Indian Journal of Science and Technology, 9(23):1-8.

Hussain, Mushtaq and Prasad Rao, T. V. D. (2013). Assessment of the ground water quality and its suitability for drinking and irrigation purposes: a case study of Patancheru, Andhra Pradesh, India, Archives of Applied Science Research, 5 (6):232-238. 
Jeihouni, M., Toomanian, A., Shahabi, M., Alavipanah, S. K. (2014). Groundwater quality assessment for drinking purposes using GIS modelling (case study: city of Tabriz), The International Archives of the Photogrammetry, Remote Sensing and Spatial Information Sciences, vol. XL-2/W3, 2014 The 1st ISPRS International Conference on Geospatial Information Research, 15-17 November 2014, Tehran, Iran, 163-168.

Mahadevaswamy, G, Nagaraju, D, Siddalingamurthy, S, Lakshmamma, Mohammad Subhan Lone, P.C. Nagesh, Krishna Rao (2011). Groundwater quality studies in Nanjangud Taluk, Mysore District, Karnataka, India, International Journal of Environmental Sciences, 1 (7):15821591.

Okoye, N. M., Orakwe, L. C., Nwachukwu, P. C. (2016). Groundwater quality mapping using GIS: a case study of Awka, Anambra State, Nigeria, International Journal of Engineering and Management Research, 6(2), 579-584.

Pandian, M., and Jeyachandran, N. (2014). Groundwater quality mapping using remote sensing and GIS-a case study at Thuraiyur and Uppiliapuram Block, Tiruchirappalli District, Tamil Nadu, India, International Journal of Advanced Remote Sensing and GIS, 3 (1), 580-591.

Patel, R. L. and Dhiman, S. D. (2011). Temporal variation and regression analysis, of groundwater quality parameters: a case study, National Conference on Recent Trends in Engineering \& Technology, 13-14 May 2011, B.V.M. Engineering College, V.V. Nagar, Gujarat, India,

Rajesh, S. (2016). Impact study of groundwater quality in Sivakasi command area, Journal of Chemical and Pharmaceutical Sciences, 9(2):238-243.

Sarkar, Atanu, Krishnapillai, Mano, Valcour, James (2012). A study of groundwater quality of private wells in Western Newfoundland Communities, Report, The Harris Centre, Memorial University, Canada, 1-25.

Satyanarayana, P., Appala Raju, N., K. Harikrishna and K. Viswanath (2013). Urban groundwater quality assessment: a case study of Greater Visakhapatnam Municipal Corporation Area (GVMC), Andhra Pradesh, India, International Journal of Engineering Science Invention, 2 (5):20-31.
Saxena, Umesh and Saxena, Swati (2015). Correlation study on physico-chemical parameters and quality assessment of ground water of Bassi tehsil of district Jaipur, Rajasthan, India, International Journal of Environment, Science and Technology, 1(1):78-91.

Sengupta, M. and Dalwani, R. (2008). Assessment of surface and groundwater quality of Hebbal Lake, Bangalorecase study, Edited Proceedings of Taal 2007:The 12th World Lake Conference,1737-1741.

Shahida Perween and Ummatul Fatima (2015). Study of groundwater quality by the assessment of physico-chemical parameters and water quality index in Aligarh, Uttar Pradesh, Journal of Chemical and Pharmaceutical Research, 7(5):761-771.

Sheikh, Muzzafar Ahmad and Kumari, Rina (2017). A geospatial approach for delineation of groundwater potential zones in a part of national capital region, India, International Research Journal of Earth Sciences, 5(10):1-10.

Sinha, A.K., Kumar, Vinay and Singh, P.K. (2018). GIS Approach based groundwater quality assessment and evaluation for irrigation purpose in a hard rock hilly terrain of Western India. International Journal of Current Microbiology and Applied Sciences, Special Issue-7:13131332.

Subramani, T., Krishnan, S., Kumaresan, P. K. (2012). Study of groundwater quality with GIS application for Coonoor Taluk in Nilgiri District, International Journal of Modern Engineering Research, 2 (3):586-592.

Thomas Spanos, Antoaneta Ene, Christina Xatzixristou, Agelos Papaioannou (2015). Assessment of groundwater quality and hydrogeological profile of Kavala area, Northern Greece, Rom. Journ. Phys.60 (7-8):1139-1150.

Topper, Ralf and Horn, Andy (2011). El Paso County groundwater quality study Phase 1, Colorado Geological Survey, 1-139.

Vashisth, Ayush (2017). Analysis of water quality of Murthal in Haryana, International Journal of Dynamics of Fluids.13 (2):243-249. 